\title{
Contribution to the Knowledge of Biodeteriogenic Flora on Three Historical Calabrian (Southern Italy) Churches
}

\author{
Maria Emanuela Mascaro, Giuseppe Pellegrino ${ }^{\circledR}$, Ida De Rose, Anna Maria Palermo* (1) \\ Department of Biology, Ecology and Earth Sciences, University of Calabria, Rende, Italy \\ Email: *anna_maria.palermo@unical.it
}

How to cite this paper: Mascaro, M.E., Pellegrino, G., De Rose, I. and Palermo, A.M. (2021) Contribution to the Knowledge of Biodeteriogenic Flora on Three Historical Calabrian (Southern Italy) Churches. Open Journal of Ecology, 11, 287-300.

https://doi.org/10.4236/oje.2021.113021

Received: January 19, 2021

Accepted: March 19, 2021

Published: March 22, 2021

Copyright $\odot 2021$ by author(s) and Scientific Research Publishing Inc. This work is licensed under the Creative Commons Attribution International License (CC BY 4.0).

http://creativecommons.org/licenses/by/4.0/

\begin{abstract}
The effect of biodeteriogenic living organisms on historical and archeological sites is a well-known problem affecting the world's cultural heritage. Indeed, the growth inside the bricks of shrubs and herbs roots can cause breakage, collapse and, detachment of materials. The knowledge of the spontaneous vascular flora present on monuments is essential for protection and safeguarding of cultural heritage. In this paper, we identify and describe biodeteriogenic vascular flora of three historical Calabrian (Southern Italy) churches, showing the relationship between plant biodiversity and exposure and building material of churches. The species present on the wall and in perimeter for each church were sampled noting substrate type, surface inclination (vertical or horizontal) and exposure. The total number of plant species recorded was 27. Hemicryptophytes (41\%) prevail over the other biological forms and the most represented families are that of the Asteraceae. Parietaria judaica is the only species present in all three sites. Substrate type, climatic condition and surface inclination affect the floristic composition. Sixteen out of 27 species grow on vertical surfaces, all Geophythes and Chamaephytes grow on horizontal surfaces, while Therophytes were rather on vertical surfaces. A significant difference was found in the Hazard Index values in the three churches. Only one site, presents a high average value of Hazard Index, due to the simultaneous presence of Ailanthus altissima, Ficus carica, Rubus ulmifolius and Sambucus nigra. The data collected indicate that the flora growing on wall of three Calabrian churches partially reflects the floristic context in which they are located. The diversity of the vegetational spectrum is remarkable, most of the plants are ruderal herbaceous, many weeds and invasive, and for the most part typical of the Mediterranean environment. The data collected contribute to the knowledge of the spontaneous vascular flora present on three historical Calabrian churches and their biodiversity, also in terms of
\end{abstract}


conservation interest, considering its biodeteriogenic potential in the evaluation of the impact of the vegetation on each monument.

\section{Keywords}

Biodeterioration, Churches, Flora, Hazard Index, Italy

\section{Introduction}

The biodeterioration of materials, defined as "any unwanted change in the properties of a material caused by the vital activity of organisms" [1] [2], is closely related both to the physical-chemical nature of the substrate and to the characteristics of the surrounding environment [3]. Therefore, it is possible to consider any artistic artifact as a real ecosystem in which there is a complex system of interactions between the organisms, the substrate on which they develop, and the environment [4].

Knowledge of flora growing on archaeological sites is extremely important both from a purely diagnostic point of view, which concerns the effects of alteration caused by biodeteriogenic organisms and from an ecological point of view, which considers the environmental context in which the monument is located. That could allow the identification of the most appropriate actions to plan the correct conservation of the asset.

The colonization of stone monuments by an organism depends on specific conditions, such as the bioreceptivity of the building material itself which relies on its chemical-physical composition, porosity, roughness of the surface, wall inclination and exposure and its state of conservation [5]. Plant colonization of walls depends on physical environmental parameters too, such as temperature, light, humidity and air movements [6].

The vascular flora can have potential biodeteriogenic effects on historical buildings, which may bring about different types of damage to the substrate on which they grow, causing breakage, collapse and, detachment of materials, mainly as a result of biophysical and biochemical processes.

Usually, biodeterioration studies concern bacteria, fungi, and algae, but in recent years, great attention has been paid to mosses and vascular flora, due to the damage caused by rhizoids and roots growth inside the stone [7] [8] [9] [10] [11]. Indeed, a significant role in the biodeterioration of historical monuments is played by higher plants. Roots tend to penetrate and grow inside the cracks already present in the masonry and zones of the least resistance (e.g., mortar between stones), thereby increasing the size of the fissures and cracks and decreasing the cohesion between stones [5] [6] [8] [12]. Our work is focused on the study of vascular flora, so we collected trees, shrubs and herbs ignoring lichens and mosses.

Moreover, the shape and the mode of growth of the root system are the factors 
on which the classification of the dangers of plant species for architectural artifacts is based [10] [13] [14].

The biochemical deterioration resulting from assimilatory processes, where the organism uses the stone surface as a source of nutrition, is probably more easily understood than the deterioration resulting from dissimilatory processes, where the organism produces a variety of metabolites that react chemically with the stone surface [15] [16].

Anatomical and morphological modifications of biodeteriogenic organisms are related to their physiological conditions, to the nature of the substrate, to the climate and the seasonal period [9] [17] [18].

The surveys designed to detect species that contribute to the deterioration of historic buildings are particularly valuable in the restoration and conservation of historical monuments and archaeological sites; however, at present, there are no studies applied to the evaluation of biodeteriogenic flora on the architectural heritage of Calabria.

The relationship between the vegetation growing in monumental environments and architectural artefacts is complex; it requires careful analysis in order to be managed correctly, respecting, on the one hand, the primary need for protection and conservation of the asset and, on the other hand, taking into consideration the aesthetic aspect linked to the presence of green and the ecological interest of the species that are present on the territory [19].

The aim of our study was therefore to identify and describe the vascular flora of three Calabrian historic churches, located in three geographic areas, with the aim of providing a plant species list, highlighting plant biodiversity, and considering its biodeteriogenic potential. We compared the effect of plants on ancient monuments based on their life form in relation to exposure and building material of churches. Moreover, we evaluated Hazard Index (HI) [13] [14], which is a measure of the potential damage that each species can cause to remains. This kind of information is necessary for the purposes of preserving the cultural landscape and for choosing appropriate management practices to prevent and eradicate vascular plants to minimise biodeterioration [20].

\section{Material and Methods}

\subsection{Study Sites}

The three historic churches object of this study are located in the Calabrian region (southern Italy) (Figure 1). Two churches are located on a hill at an altitude 450 and $566 \mathrm{~m}$ a.s.l., near Montalto Uffugo and San Fili (Cosenza, Calabria, Italy), respectively. The third is situated in the ancient village of Squillace (Catanzaro, Calabria, Italy), at $340 \mathrm{~m}$ a.s.l. and close to the Ionian Sea (just $5 \mathrm{~km}$ as the crow flies). The main climatic characteristics of these three sites are summer drought and moderate winter cold, with an average annual temperature of $15^{\circ} \mathrm{C}$, although the town of Squillace is very influenced by the proximity of the sea, and it's rainy in the winter months and drier in the summer than the other two sites. 


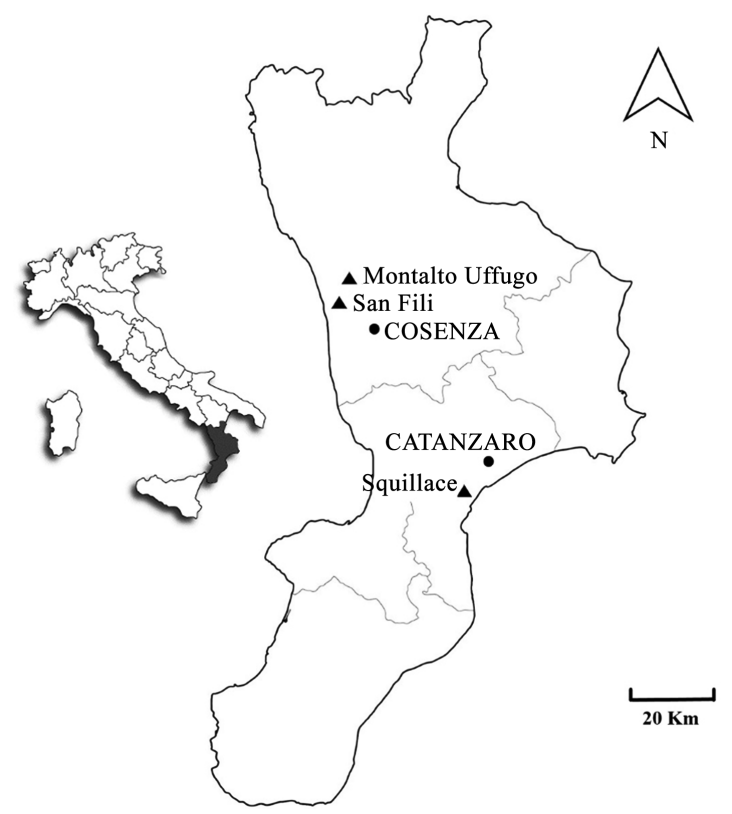

Figure 1. Location of the study areas in Calabria (Southern Italy).

\subsection{Historical Background and Buildings Description}

The Church of Santa Maria della Serra in Montalto Uffugo (SMS) (Figure 2(A)), dates back to 1227 and stands on a hill in a peripheral position from the center of the village of Montalto Uffugo. Over the centuries, it has undergone numerous restorations due to the disastrous earthquakes that damaged it over time. The restoration work continued for about thirty years but left the upper part of the main facade incomplete, therefore it is made up of exposed bricks. The Church, originally in Romanesque style and initially composed of a Greek cross plan with three naves, later assumed a planimetric layout with Latin cross plants and architectural solutions in Baroque style [21].

The central portal is surmounted by a niche with the reproduction of the statue of the Madonna della Serra. The entire facade is decorated with a triumph of geometric and naturalistic embroidery.

The Mother Church of the Santissima Annunziata in San Fili (SA) (Figure 2(B)) dominates the town and strongly characterizes the urban layout of the whole village of San Fili. The church has been documented since the seventeenth century and was enlarged at the end of the 18th century. The principal facade, unfinished in the upper part, is connected to the churchyard by a wide staircase leading to the portal. Today the church is divided into three naves; the main entrance consists of a round arch cleverly carved with floral motifs and acanthus leaves [21] [22].

Lastly, the Church of Santa Maria della Pietà in Squillace (SMP) (Figure 2(C)), so-called "Gothic church", is protected from urban and anthropic pollution and is not exposed to winds because it is sheltered by surrounding houses that shield it from the sun. It is one of the rare Gothic architectural artifacts in Calabria, dating back to the 13th century. It consists of an almost square plan. On the 

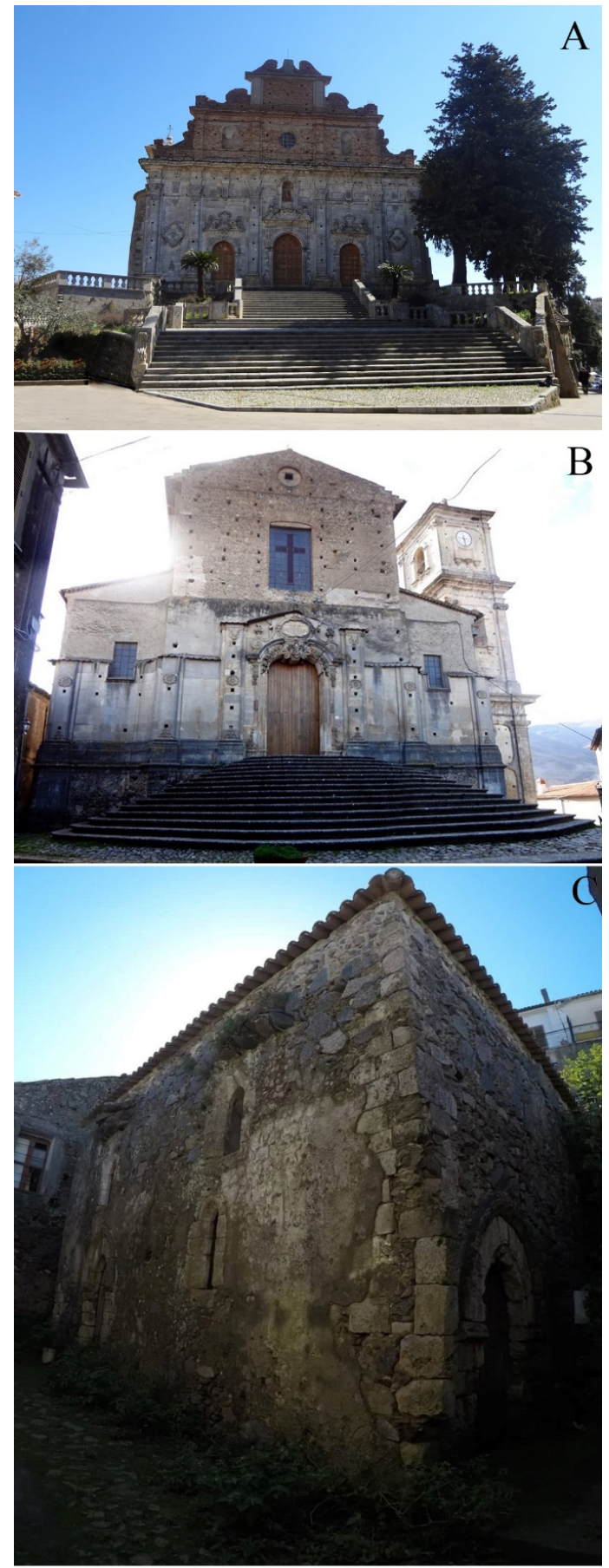

Figure 2. Historical churches: A-Santa Maria della Serra, B-Santissima Annunziata, C-Santa Maria della Pietà.

external facade exposed to the east, which is the only one of the four entirely visible as the others are occluded by an embankment, there are four single windows and a finely framed portal. Inside the building is divided into four spans with cross vaults supported by four semi-piers, four-corner columns and a large square central pillar having a very unique position because it is placed obliquely with respect to the perimeter of the walls. This building is erroneously called 
"church" but the real intended use of this building is not documented. Probably it's what remains of a "domus scolaciorum" of a civil-military character [23].

\subsection{Substrates and Conservation Status}

The facades of SMS and SA consist of white-yellowish (SA) or reddish (SMS) fossiliferous calcarenites [24] commonly known as "Mendicino limestone". This limestone, definite as biocalcarenite/calcirudite [25], is predominantly composed of sand-sized debris and carbonate grains consisting of fragments of older limestones and dolomites, other carbonate grains and clasts of biological origin such as marine organism fossils (corals, shells, ooids). It appears as a porous and medium-resistant material, chromatically variable depending on the more or less abundant presence of iron oxides [26].

The SMP building is mainly composed of carbonate rock characterized by a microsparitic texture rich in iron oxides, a medium-high level of porosity and a content of calcite higher than $90 \%$ [27]. The external wall structure is made up of irregular stone blocks, among which we can see fragments of terracotta. The mortars and plasters used for the construction and lining of the external walls have a very heterogeneous composition made mainly of quartz, feldspars, biotite and fragments of magmatic and metamorphic rocks.

The different building materials are linked to the geographical position; materials readily available in the vicinity were used for the construction of the churches.

For what concerns the state of conservation SMS has numerous spots affected by chromatic alteration, biological patinas, and black crusts in areas less exposed to rain on the main facade. At various points, especially under the cornice and on the sill of the central niche, there are phenomena of exfoliation and erosion of the masonry.

The church of SA presents an important form of chromatic alteration on the lower part of the main facade. The washout spots and biological patinas and black crusts are also conspicuous at various points. The upper part of the portal shows evident shortcomings and detachments of the masonry.

The SMP shows various pathologies of degradation, all of them due to the particular position of the building, which is located in a narrow blind lane and is surrounded by taller buildings: this makes the area not very sunny and ventilated. For the environmental conditions and for the characteristics of hygroscopicity and porosity typical of the materials used for its construction, inside the building the rate of relative humidity is very high throughout the year, as well as the ascent capillary water from the ground which, therefore, can be considered the main cause of all the deterioration phenomena present on the entire wall structure: masonry lesions, exfoliation, detachment, and sulphation of the plasters, salt efflorescence, biological attack and infesting vegetation.

\subsection{Sampling}

The field investigation for the detection of vascular plants present on the outside 
of the buildings was carried out from the Spring of 2016 to the autumn of 2017. The species present on the walls (W) and those in its perimeter (WP) were sampled. For each sampling unit the following data were supplied: site name, substrate, position (vertical or horizontal) and exposure.

Besides a careful observation in situ, the small plants have been collected in their entirety and, for the large ones, only the portions of the air parts visible at the time of sampling (ex. leaves, flowers, fruits, seeds) were taken. The voucher specimens were deposited in herbarium of Plant Biosystem Laboratory (University of Calabria, UniCal) and, in addition, a detailed photographic documentation has been produced.

The species identification was carried out according to Pignatti [28] [29] [30] [31] and Tutin [32] with the method of the dichotomous keys for the taxonomic characterization. The nomenclature follows the checklist of Italian vascular flora [33] [34]. Families are organised based on APG IV for angiosperms [35].

To evaluate the hazard of the biodeteriogen species for the building, for each taxon the Hazard Index (HI) [13] [14] was evaluated. This numerical index, ranging from 0 (minimal hazard) to 10 (high hazard), differs for each species and is often variable even within the same species [7]. To obtain the HI of each church, the $\mathrm{HI}$ of different species within each sample was summed and the average was calculated for each church. According to Raunkier [36] the plant form life has been determined.

\section{Result}

Table 1 lists in alphabetical order all the species detected in the three sites. The flora listed comprises 27 plant species, classified into 26 genera and 15 families, among which the most representative are the Asteraceae (26\%).

The 27 plant species detected were subdivided into two microhabitats, according to their position compared to buildings: on the walls (16 taxa), on the perimeter of the walls (11 taxa), and (Figure 3 ).

A difference in terms of number of plant species among sites was highlighted. More than half of the total species were found in the churches of SMS (12 taxa) and SMP (15 taxa), while only 5 species were identified in SA. The only species present in all three sites was Parietaria judaica. SMP shares Erigeron canadiensis and Taraxacum officinale with SMS, while the latter shares only Hordeum murinum with SA.

The analysis of biological life forms showed five different shapes, with the predominance of Hemicryptophytes (11 species, 40.7\%) in all tree churches. Also Therophytes (7 species, $26 \%$ ) were common in all sites, whereas Chamaephytes (2 species, 7.4\%) were present only in SMS and Phanerophytes (4 species, 14.8\%) and Geophythes (3 species, 11.1\%) only in SMP (Figure 4, Table 1). Sixteen out 27 species grow on vertical surfaces, all Geophythes and Chamaephytes were on horizontal surfaces, while Therophytes grow rather on vertical surfaces. 


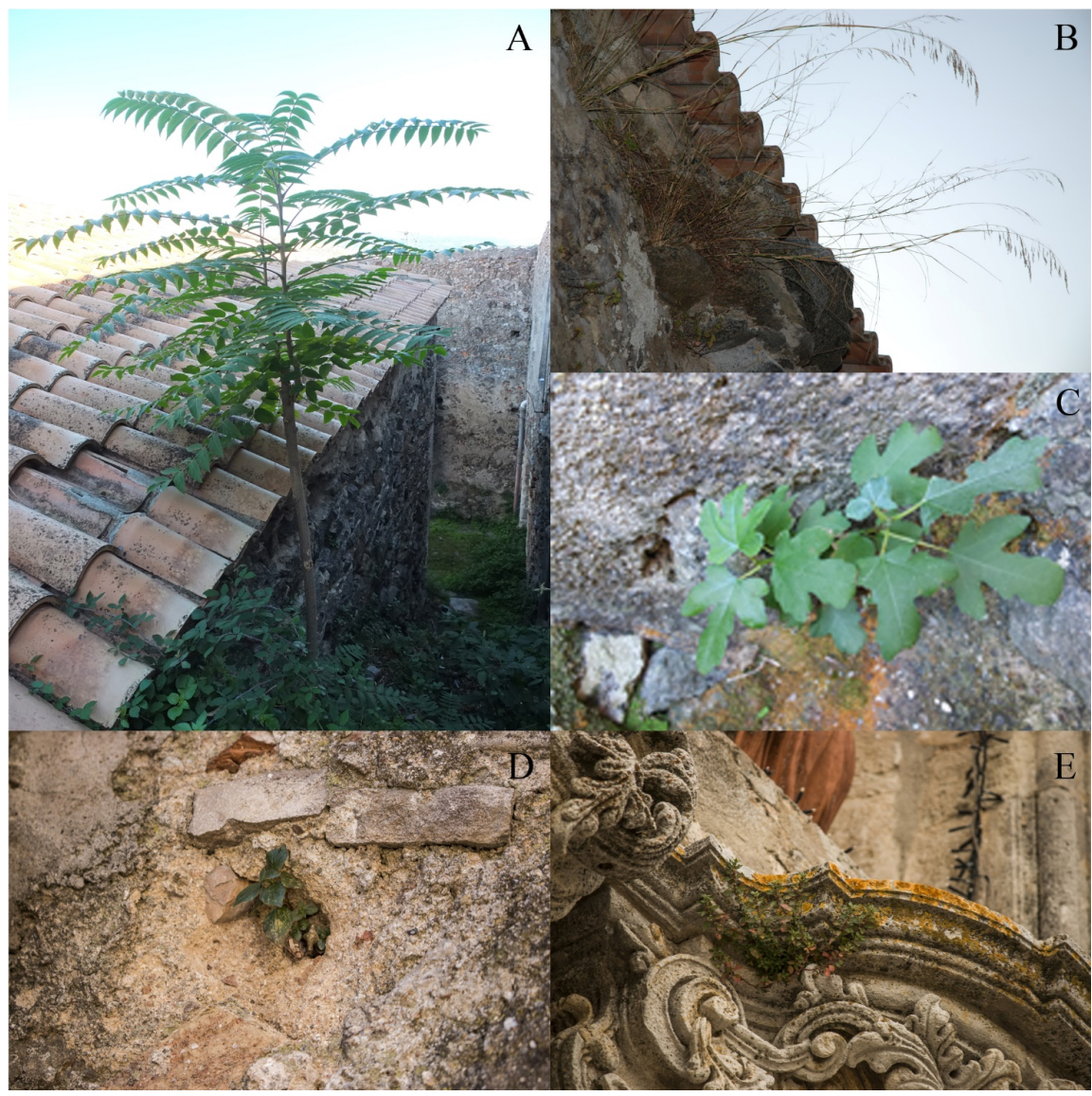

Figure 3. Biodeteriogen species colonising the architectural elements of churches. A-Ailanthus altissima; B-Hordeum murinum; C-Ficus carica; D-Parietaria judaica; $\mathrm{E}-$ Micromeria graeca.

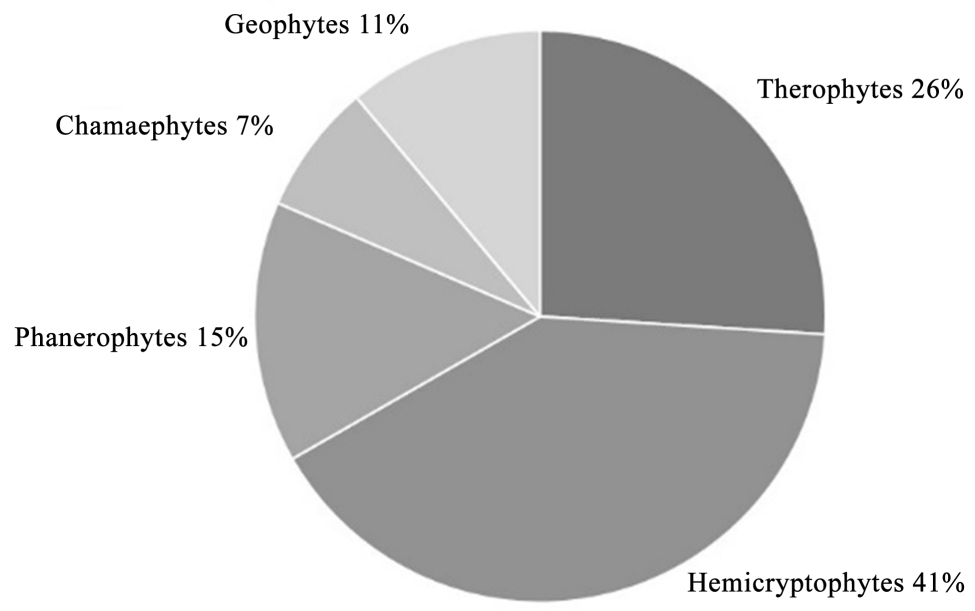

Figure 4. Plant life form spectrum.

The Hazard Index (HI), used to evaluate the biodeteriogenic potential, showed that $18.5 \%$ of the species were not very hazardous (HI from 0 to 3 ), $66.7 \%$ were somewhat hazardous (HI 4 to 6 ), and $14.8 \%$ were very hazardous (HI 7 to 10$)$. 
Table 1. Inventory of all the vascular flora species detected in the three sites: Church of Santa Maria della Serra in Montalto Uffugo (SMS), Church of the Santissima Annunziata in San Fili (SA) and Church of Santa Maria della Pietà in Squillace (SMP). HI = Hazard Index, $\mathrm{W}=$ wall, $\mathrm{WP}=$ wall perimeter.

\begin{tabular}{|c|c|c|c|c|c|c|c|}
\hline Species & Family & Plant life form & $\mathrm{HI}$ & SMS & SA & SMP & Position \\
\hline $\begin{array}{c}\text { Ailanthus altissima (Mill.) } \\
\text { Swingle }\end{array}$ & Simaroubaceae & P scap & 10 & & & + & $\mathrm{W}$ \\
\hline Anthemis arvensis $\mathrm{L}$. & Asteraceae & T scap & 1 & + & & & WP \\
\hline Crepis neglecta $\mathrm{L}$. & Asteraceae & T scap & 2 & + & & & $\mathrm{W}$ \\
\hline Diplotaxis tenuifolia (L.) Dc. & Brassicaceae & H scap & 5 & & & + & WP \\
\hline Dittrichia viscosa (L.) Greuter & Asteraceae & H scap & 5 & & + & & $\mathrm{W}$ \\
\hline Erigeron canadiensis $\mathrm{L}$. & Asteraceae & T scap & 4 & + & & + & WP \\
\hline Ficus carica L. & Moraceae & P scap & 10 & & & + & $\mathrm{W}$ \\
\hline Hordeum murinum $\mathrm{L}$. & Poaceae & T scap & 0 & + & + & & $\mathrm{W}$ \\
\hline Leontodon hispidus L. & Asteraceae & $\mathrm{H}$ ros & 4 & + & & & WP \\
\hline Mentha pulegium $\mathrm{L}$. & Lamiaceae & H scap & 5 & & + & & $\mathrm{W}$ \\
\hline Micromeria graeca (L.) Benth. & Lamiaceae & Ch suffr & 4 & + & & & $\mathrm{W}$ \\
\hline Mirabilis jalapa L. & Nyctaginaceae & G bulb & 6 & & & + & $\mathrm{W}$ \\
\hline Parietaria judaica L. & Urticaceae & H scap & 5 & + & + & + & $\mathrm{W}$ \\
\hline Phytolacca americana L. & Phytolaccaceae & G rhiz & 6 & & & + & $\mathrm{W}$ \\
\hline Picris hieracioides $\mathrm{L}$. & Asteraceae & H bienn/H scap & 6 & & & + & $\mathrm{W}$ \\
\hline Plantago lanceolata L. & Plantaginaceae & $\mathrm{H}$ ros & 6 & + & & & $\mathrm{W}$ \\
\hline Polycarpon tetraphyllum (L.) L. & Caryophyllaceae & T scap & 1 & & + & & WP \\
\hline Rubus ulmifolius Schott. & Rosaceae & P caesp & 8 & & & + & $\mathrm{W}$ \\
\hline Sambucus nigra $\mathrm{L}$. & Adoxaceae & P caesp & 8 & & & + & WP \\
\hline Sanguisorba minor Scop. & Rosaceae & H scap & 6 & & & + & $\mathrm{W}$ \\
\hline Sorghum halepense (L.) Pers. & Poaceae & G rhiz & 6 & & & + & $\mathrm{W}$ \\
\hline Taraxacum officinale $\mathrm{Web}$. & Asteraceae & $\mathrm{H}$ ros & 6 & + & & + & WP \\
\hline Trachelium caeruleum $\mathrm{L}$. & Campanulaceae & Ch suffr & 4 & + & & & $\mathrm{W}$ \\
\hline Trifolium pratense $\mathrm{L}$. & Fabaceae & T scap & 6 & + & & & WP \\
\hline Trifolium repens $\mathrm{L}$. & Fabaceae & H rept & 5 & + & & & WP \\
\hline Urtica dioica $\mathrm{L}$. & Urticaceae & H scap & 5 & & & + & WP \\
\hline Veronica polita Fr. & Plantaginaceae & T scap & 3 & & & + & WP \\
\hline
\end{tabular}

A significant difference was found in the HI values in the three sites examined (Figure 5, Table 1). Indeed, only the church of SMP showed a high average value of Hazard Index (HI 6.3), due to the presence of 4 species with high values, Ailanthus altissima and Ficus carica (HI 10), Rubus ulmifolius and Sambucus nigra (HI 8). The other 2 churches, SMS and SA, showed much lower average values, 3.9 and 3.2, respectively: in these two sites $65 \%-75 \%$ of the species found had an intermediate HI value between 4 and 6 . 


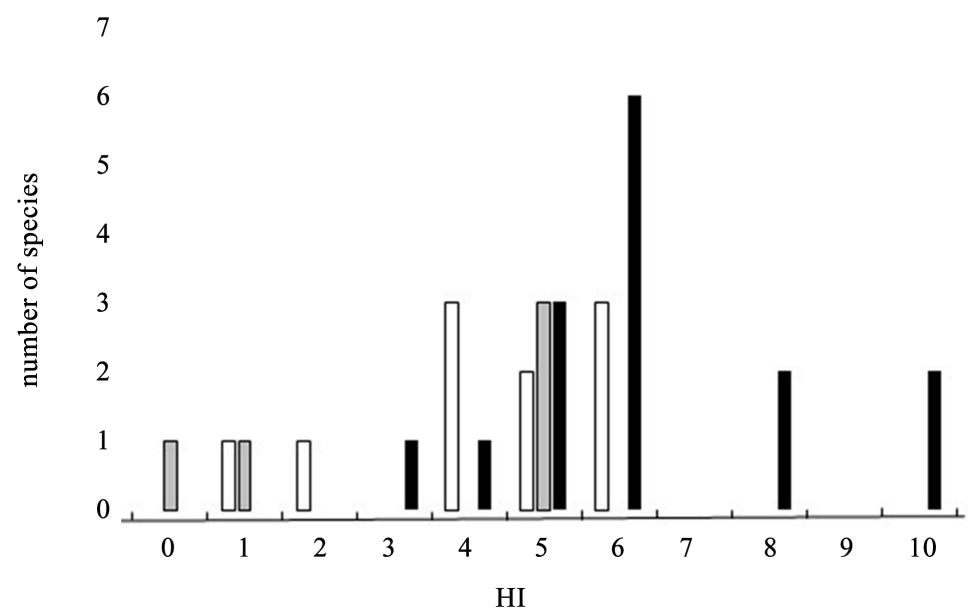

Figure 5. Hazard Index at the three study sites with relative number of species. Church of Santa Maria della Serra in Montalto Uffugo (SMS, white bars), Church of the Santissima Annunziata in San Fili (SA, gray bars) and Church of Santa Maria della Pietà in Squillace (SMP, black bars).

\section{Discussion}

Our data indicate that the flora growing on wall of churches partially reflects the floristic context in which the churches are located, dominated by species associated with agicultural environment and natural areas. Indeed, most species are typically ruderal (Crepis neglecta, Diplotaxis tenuifolia, Picris hieracioides, Hordeum murinum, Parietaria judaica and Urtica dioica) and few are invasive (e.g. Ailanthus altissima, Mirabilis jalapa) [37].

The examined churches share the presence of some plant species suggesting that the different substrates of the walls (white-yellowish or reddish fossiliferous calcarenites and carbonate) do not influence the growth of plants.

Most species are spontaneously present on the walls and include trees (Ailanthus altissima, Ficus carica), shrubs (Dittrichia viscosa, Micromeria graeca, Rubus ulmifolius, Trachelium caeruleum) annual herbacious plants (Crepis neglecta, Hordeum murinum,) and perennial herbacious plants (Mentha pulegium, Mirabilis jalapa, Parietaria judaica, Phytolacca americana, Plantago lanceolata, Picris hieracioides, Sanguisorba minor, Sorghum halepense). Among these there are the most dangerous species with a high HI value (8 - 10) such as Ailanthus altissima, Ficus carica, Rubus ulmifolius and Sambucus nigra, which are characterized by imposing and robust roots creeping in the junction points between the bricks of construction, using cracks and pre-existing fractures, causing the disintegration of mortars and plasters up to the foundations of the buildings. On the perimeter of the walls of the buildings are dominant annual and perennial herbaceous species (e.g. Anthemis arvensis, Erigeron canadiensis) which have a medium-low average HI, such as Parietaria judaica or Plantago lanceolata, HI 5 and 6, respectively. They are almost all specimens with a generally not very developed root system, therefore they do not represent a big risk for the stability and the mechanical resistance of the walls. 
Previous studies reported that horizontal surfaces, which provide better growing conditions, usually host a higher plant cover compared to vertical walls [38] [39]. In our case, more species were detected on vertical than on horizontal surfaces in agreement with Motti et al. 2020 [40]. However, in contrast to [40] and [41] in our sites Therophytes were more common on horizontal surfaces, while Geophythes and Chamaephytes, the most biodeteriogenic life forms, were on vertical surfaces.

The plant life forms revealed the presence of Hemicryptophytes and Therophytes in all three examined sites; the former were found predominantly on the walls while the latter are more abundant along the wall perimeter of the churches. Woody life forms accounted for only 25.9\% in agreement with Francis [42], while the greater presence of Hemicryptophytes is related to human disturbance and climatic condition [7].

The largest number of species (15 taxa) was found on the site of Church of Santa Maria della Serra in Montalto Uffugo (SMP), which despite its small extension, presents a wide variety of biological forms with greater amounts of hemicriptophytes (6 taxa) and herbaceous, biennial or perennial plants. All vascular species with higher $\mathrm{HI}$ are also present on this church. In addition, there are non-native species of Italian flora that have become naturalized, and are all neophytes /invasive (Ailanthus altissima, Erigeron canadiensis, Mirabilis jalapa, Phytolacca americana and Sorghum halepense), probably related to the synanthropic environment represented by churches. There is a high variety of species typical of Mediterranean environments influenced by the proximity of the sea and by the climatic condition characterized by summer drought and moderate winter cold, with an average annual temperature of $15^{\circ} \mathrm{C}$.

Also in the site of SMS the total number of species (12) found is quite high; there is an equitable distribution of hemicyptophytes and therophytes (5 species) and also the only two detected Chamaephytes belong to this site. Erigeron canadiensis is the only naturalized neophyte species and Plantago lanceolata is a synanthropic species that adapts to almost all climates and soils. Most of the species found are annual and perennial herbaceous plants, except for two shrub species (Micromeria graeca and Trachelium caeruleum). The church is located in the center of the town of Montalto Uffugo but in a quite open area, free from obstacles, and with land around.

Finally, the church of the SA is the one where the least number of plants (5 taxa) have been collected. All the species identified are typically ruderal and weeds, with a value of $\mathrm{HI}$ between 0 and 5 . The church is incorporated into the urban context and is enclosed by the surrounding buildings, which could explain the scarce variety of the species found. This is probably due to the difficulty for seeds to be conveyed in such narrow spaces and to settle on the facades and on the external perimeter.

\section{Conclusions}

The data collected contribute to the knowledge of the spontaneous vascular flora 
present on three historical Calabrian churches. Our data provided useful information on cultural heritage for understanding the relationship between plant biodiversity and abiotic factors (substrate type, climatic condition, exposure).

Our results confirm that plants constitute valid bioindicators of the "state of health" of the monuments. Due to their characteristics (life form, pollination and seed dispersal) and the Hazard Index suggestions, most of the listed plants are biodeteriogenic for these churches especially considering their building materials.

Information contained in this work can contribute to a better control of the growth of these species on church wall, since many of them are threatening the integrity of the ancient monuments due to their vigorous root apparatus penetrating into the brick structures. Finally, this knowledge can find applications in the conservation and restoration activities of ecclesiastical heritage.

\section{Conflicts of Interest}

The authors declare no conflicts of interest regarding the publication of this paper.

\section{References}

[1] Hueck, H.J. (1965) The Biodeterioration of Materials as a Part of Hylobiology. Material und Organismen, 1, 5-34.

[2] Hueck, H.J. (1968) The Biodeterioration of Materials-An Appraisal. In: Walters, A.H. and Elphick, J.S., Eds., Biodeterioration of Materials, Elsevier, London, 6-12.

[3] Caneva, G., Nugari, M.P. and Salvadori, O. (2007) La Biologia Vegetale per i Beni Culturali. Vol. 1: Biodeterioramento e Conservazione. Nardini editore, Firenze.

[4] Zari, M.P. (2018) The Importance of Urban Biodiversity-An Ecosystem Services Approach. Biodiversity International Journal, 2, 357-360. https://doi.org/10.15406/bij.2018.02.00087

[5] Lisci, M., Monte, M. and Pacini, E. (2003) Lichens and Higher Plants on Stone: A Review. International Biodeterioration and Biodegradation, 51, 1-17. https://doi.org/10.1016/S0964-8305(02)00071-9

[6] Mishra, A.K., Jain, K.K. and Garg, K.L. (1995) Role of Higher Plants in the Deterioration of Historic Buildings. Science of the Total Environment, 167, 375-392. https://doi.org/10.1016/0048-9697(95)04597-T

[7] Motti, R. and Stinca, A. (2011) Analysis of the Biodeteriogenic Vascular Flora at the Royal Palace of Portici in Southern Italy. International Biodeterioration and Biodegradation, 65, 1256-1265. https://doi.org/10.1016/j.ibiod.2010.03.010

[8] Mishra, G.K. and Saini, D.C. (2016) Biodeterioration of Wall and Roof in Historic Building and Monuments in Lucknow City Uttar Pradesh. Journal on New Biological Reports, 5, 10-18.

[9] Motti, R. and Bonanomi, G. (2018) Vascular Plant Colonisation of Four Castles in Southern Italy: Effects of Substrate Bioreceptivity, Local Environment Factors and Current Management. International Biodeterioration and Biodegradation, 133, 26-33. https://doi.org/10.1016/j.ibiod.2018.06.004

[10] Dahmani, J., Benharbit, M., Fassar, M., Hajila, R., Zidane, L., Magri, N. and Belahbib, N. (2020) Vascular Plants Census Linked to the Biodeterioration Process of the 
Portuguese City of Mazagan in El Jadida, Morocco. Journal of King Saud University-Science, 32, 682-689. https://doi.org/10.1016/j.jksus.2018.10.015

[11] Caneva, G., Galotta, G., Cancellieri, L. and Savo, V. (2009) Tree Roots and Damage in the Jewish Catacombs of Villa Torlonia (Roma). Journal of Cultural Heritage, 10, 53-62. https://doi.org/10.1016/j.culher.2008.04.005

[12] Gill, W.R. and Bolt, G.H. (1955) Pfeffer's Studies of the Root Growth Pressures Exerted by Plants. Agronomy Journal, 47, 166-168. https://doi.org/10.2134/agronj1955.00021962004700040004x

[13] Signorini, M.A. (1995) Lo Studio e il Controllo della Vegetazione Infestante nei Siti Archeologici. Una Proposta Metodologica. In: Marino, L. and Nenci, C., Eds., L'area Archeologica di Fiesole. Rilievi e Ricerche per la Conservazione, Comune di Fiesole. C.N.R. Centro di Conservazione Opere d'Arte, Roma. Università di Firenze: Dip. Di Biologia Vegetale, Dip. di Scienze della Terra, Dip. di Storia dell'Architettura e Restauro delle Strutture Architettoniche. Alinea, Firenze, 41-46.

[14] Signorini, M.A. (1996) L'Indice di Pericolosità: un Contributo del Botanico al Controllo della Vegetazione Infestante nelle Aree Monumentali. Informatore Botanico Italiano, 28, 7-14.

[15] Mortland, M.M., Lawton, K. and Uehara, G. (1956) Alteration of Biotite to Vermiculite by Plant Growth. Soil Science, 82, 477-482.

https://doi.org/10.1097/00010694-195612000-00004

[16] Caneva, G. and Altieri, A. (1988) Biochemical Mechanisms of Stone Weathering Induced by Plant Growth. In: Ciabach, J., Ed., Proceedings of the VIth International Congress on Deterioration and Conservation of Stone, Nicholas Copernicus University, Torun, 32-44.

[17] Kumbaric, A., Ceschin, S., Zuccarello, V. and Caneva, G. (2012) Main Ecological Parameters Affecting the Colonization of Higher Plants in the Biodeterioration of Stone Embankments of Lungotevere (Rome). International Biodeterioration \& Biodegradation, 72, 31-41. https://doi.org/10.1016/j.ibiod.2012.02.009

[18] Pinna, D. and Salvadori, O. (2007) Meccanismi Generali dei Processi di Biodeterioramento. In: Caneva, G., Nugari, M.P. and Salvadori, O., Eds., La Biologia Vegetale per i Beni culturali, Vol. I, Nardini Editore, Firenze, 15-34.

[19] Pacini, E. and Signorini, M.A. (2009) Vascular Plants. In: Caneva, G., Nugari, M.P. and Salvadori, O., Eds., Plant Biology for Cultural Heritage: Biodeterioration and Conservation, Getty Publications, Los Angeles, 87-96.

[20] Caneva, G. and Ceschin, S. (2009) Ecology of Biodeterioration. In: Caneva, G., Nugari, M.P. and Salvadori, O., Eds., Plant Biology for Cultural Heritage: Biodeterioration and Conservation, Getty Publications, Los Angeles, 35-58.

[21] Chimirri, R. (2008) Atlante storico dell'architettura in Calabria. Tipologie Colte e Tradizionali. Rubettino Editore, Soveria Mannelli (Cz), Italy.

[22] Jusi, G. (1974) La Ricostruzione della Chiesa Parrocchiale di San Fili (1748-1802), Pellegrini, Cosenza.

[23] Ferraro Pelle, C. (1980) La Cosiddetta Chiesetta di S. Maria della Pietà a Squillace: Problemi ed Aspetti del Restauro in un Prezioso Esempio di Architettura Gotica Calabrese. I Beni Culturali e le Chiese di Calabria: Atti del Convegno Ecclesiale Regionale Promosso dalla Conferenza Episcopale Calabra, Reggio Calabria-Gerace, 24-26 ottobre 1980, Vol. 37, 477-479.

[24] Burton, A. (1973) Note Illustrative delle Tavolette Appartenenti al Foglio 236 di Cosenza, Cassa per il Mezzogiorno. Poligrafica e Cartevalori, Ercolano, 30.

[25] Mastandrea, A., Muto, F., Neri, C., Papazzoni, C.A., Perri, E. and Russo, F. (2002) 
Deep-Water Coral Banks: An Example from the "Calcare di Mendicino" (Upper Miocene, Northern Calabria, Italy). Facies, 47, 27-42. https://doi.org/10.1007/BF02667704

[26] Forestieri, G., Campolongo, A. and Ponte, M. (2016) La Pietra e l'Architettura. Analisi Storica e Materica del Materiale Lapideo nel Territorio di Cosenza. History of Engineering Proceedings of the 2nd International Conference, Naples, 22-23 April 2016, Vol. 1, 213-222.

[27] Giannotti, G.B. (2009) Analisi Stratigrafiche sugli Intonaci di S. Maria della Pietà di Squillace. Architetti Catanzaro news. Rivista semestrale dell ordine degli architetti, pianificatori, paesaggisti e conservatori della provincia di Catanzaro, 1, 40-41.

[28] Pignatti, S. (1982) Flora d'Italia. Edagricole, Bologna.

[29] Pignatti, S., Guarino, R. and La Rosa, M. (2017) Flora d'Italia. Vol. 1, Edagricole, Bologna.

[30] Pignatti, S., Guarino, R. and La Rosa, M. (2017) Flora d'Italia. Vol. 2, Edagricole, Bologna.

[31] Pignatti, S., Guarino, R. and La Rosa, M. (2018) Flora d'Italia. Vol. 3, Edagricole, Bologna.

[32] Tutin, T.G., Burges, N.A., Chater, A.O., Edmondson, J.R., Heywood, V.H., Moore, D.M., Valentine, D.H., Walters, S.M. and Webb, D.A. (1993) Flora Europaea 1. Second Edition, Cambridge University Press, Cambridge.

[33] Bartolucci, F., et al. (2018) An Updated Checklist of the Vascular Flora Native to Italy. Plant Biosystems - An International Journal Dealing with all Aspects of Plant Biology, 152, 179-303.

[34] Galasso, G., et al. (2018) An Updated Checklist of the Vascular Flora Alien to Italy. Plant Biosystems-An International Journal Dealing with All Aspects of Plant Biology, 152, 556-592.

[35] Chase, M.W., et al. (2016) An Update of the Angiosperm Phylogeny Group Classification for the Orders and Families of Flowering Plants: APG IV. Botanical Journal of the Linnean Society, 181, 1-20. https://doi.org/10.1111/boj.12385

[36] Raunkiaer, C. (1934) The Life Forms and Statistical Plant Geography. Oxford Clarendon Press, Oxford.

[37] Celesti-Grapow, L. and Blasi, C. (2004) The Role of Alien and Native Weeds in the Deterioration of Archaeological Remains in Italy. Weed Technology, 18, 1508-1514. https://doi.org/10.1614/0890-037X(2004)018[1508:TROAAN]2.0.CO;2

[38] Caneva, G., De Marco, G., Dinelli, A. and Vinci, M. (1992) The Wall Vegetation of the Roman Archaeological Areas. Science and Technology for Cultural Heritage, 1, 217-226.

[39] Ceschin, S., Bartoli, F., Salerno, G., Zuccarello, V. and Caneva, G. (2016) Natural Habitats of Typical Plants Growing on Ruins of Roman Archaeological Sites (Rome, Italy). Plant Biosystems - An International Journal Dealing with all Aspects of Plant Biology, 150, 866-875. https://doi.org/10.1080/11263504.2014.990536

[40] Motti, R., Bonanomi, G. and Stinca, A. (2020) Deteriogenic Flora of the Phlegraean Fields Archaeological Park: Ecological Analysis and Management Guidelines. Nordic Journal of Botany, 38, 1-11. https://doi.org/10.1111/njb.02627

[41] Duchoslav, M. (2002) Flora and Vegetation of Stony Walls in East Bohemia (Czech Republic). Preslia, 74, 1-26.

[42] Francis, R.A. (2010) Wall Ecology: A Frontier for Urban Biodiversity and Ecological Engineering. Progress in Physical Geography, 35, 43-63.

https://doi.org/10.1177/0309133310385166 